DOI https://doi.org/10.36059/978-966-397-108-7/105-126

\title{
SURREALISM AT THE SERVICE OF REVOLUTION - ? REVOLUTION AS A SCANDAL OF EXPOSURE
}

\section{Predeina M. Yu.}

\section{INTRODUCTION}

Article Mic. Lifshits "Why am I not a modernist?" was published in 1963 in Estetika Prague and three years later reprinted in Russian in the Literary Gazette. The matter is long-standing, but the questions posed by the article or that rise after reading of the article are not yet resolved. First of all, what are these questions? - The question can be formulated historically, how did it happen that such an educated and even honest aestheticist as Mikhail Lifshits took a position against the avant-garde? Rather, along these lines, the spring exhibition of last year, devoted to M. Lifshits and held by the Moscow Museum of Modern Art Garage, poses the question. It is responsible for this question, because the position of Mic. Lifshits is Marxist position itself. The organizers of the exhibition, in essence, agree with Lifshits that Marxism is hostile to the avant-garde, and if this conclusion does not sound like a verdict to the avant-garde, it is only because they are not Marxists, i.e. because the question of the relation of Marxism to the avant-garde (and vice versa) they are no longer interested, or rather, interested in terms of what was passed. It is precisely this lack of interest that allows them to say ordinary enough: while the majority of the Soviet intelligentsia turned away from Marxism, this very majority condemned Lifshitz's article as apostasy (apostasy from what?), Lifshits remained his firm supporter ${ }^{1}$. But why should we assume that the majority is already alienated and one Lifshits remained firm? This explanation hides from us the fact that the vanguard did not perceive itself as something anti-Marxist, rather, on the contrary. - Of course, not all avant-garde declared its Marxist sympathies, but, for example, Andre Breton stated and even was friends with Leon Trotsky, of course, even in the 60s the fact of such friendship could be regarded as evidence of the opposite of what I intend to prove. In other words the proof of the fascist

1 See: «Если бы наша консервная банка заговорила... Михаил Лифшиц и советские шестидесятые» 7 марта - 13 мая 2018. М.: Музей современного искусства «Гараж», 2018, с. 3. 
character of avant-garde art. It certainly could be regarded like this but not by Lifshits. We must pay tribute to Lifshits he does not use such simple arguments, otherwise the case of the avant-garde could be closed by pinning Marinetti, who did not hide his love for Mussolini. That is, Lifshits would probably agree to recognize Andre Breton's subjective honesty just as he recognized Pablo Picasso's subjective honesty before. Oddly enough, in his article it was Picasso who is to blame. Although it may not be strange: Lifshits didn't look for easy ways, and Picasso's subjective honesty was beyond doubt. How Marx loved to write: "Here Rhodes is here and jump!", that is, "Here is Picasso - prove that his art leads logically (!) To fascism". - But what if not "Guernica" by Picasso, is a better accusation against fascism, presented by means of art? "All things are considered, the question that I intend to reveal will not sound in the past, but in the present tense: how can a Marxist perceive the avantgarde?" Because this is precisely the problem and the difference in the answers to this question at some even sensual level divorces us, first of all, with the French "left" - we are too correct.

The question "how a Marxist should perceive the avant-garde?" Is not an illegitimate mixture of the political and the aesthetic, since it is legitimate or not the political and aesthetic were mixed long ago (or maybe they were always mixed?). - Jean Baudrillard called such a situation that the aesthetic goes beyond its borders, mixing the aesthetic with the political called "trans-aesthetic". - When Lifshits charges the avant-garde art with fascism, he, among other things (besides political assessments), seeks to arouse a feeling of disgust in us, as in political animals, or rather, as in people equipped with specific political sensuality. And this is not an inappropriate attack against the avant-garde, since the avant-garde itself appeals precisely to our political sensuality. When you look at the crumpled drums from under the chemicals of Joseph Beuys (exposition "Room of 90 thousand German marks"), you can enjoy anything, but not beauty. And who said that art should give you the pleasure of beauty? - What is it? Is exposed sale price of barrels economic or political? What if we are these barrels also crumpled and also sold? In order to see something, we must look politically, otherwise ... Otherwise, we get all these jokes like you can go to the dump instead of a museum.

Lifshits, if we agree with him, will not only arouse in us a feeling of disgust for the avant-garde, but also deprive us of the ability to see the 
avant-garde, because seeing the avant-garde can only be politically, and seeing politically associates with Marx. The paradox is that while Soviet aesthetics exposes the avant-garde as anti-Marxist, Western aesthetics reveals Marx's Capital through avant-garde, says Avant-garde language in Capital, for example, Thierry de Duv's The Slaves of Marx. - Strictly speaking, de Duve's "Capital" is made with the help of conscious Joseph Beuys and irresponsible Marcel Duchamp. The logic of "Capital" can be traced in the works of each of them, wittingly or unwittingly.

As I have already had occasion to notice, I take surrealism because firstly, it is impossible to embrace the whole avant-garde in one article, secondly, Andre Breton, the founder of surrealism, clearly stated his political position and began to publish the magazine, which is as suitable as possible for the purposes of my article - "Surrealism in the service of the revolution." But just like de Duve, I will not limit myself to a conscious Breton, but I will also attract the unconscious Marcel Duchamp. The division is not a simple thing, especially since the conscious and the non-conscious can work together, as was the case with Luis Bunuel and Salvador Dali. - Finally, I will not investigate the question of Marx`s opinion about Wagner, because no matter what anyone thinks about Wagner, Wagner is pretty far from our subject. I will be much more interested in the manifestation of Marx's logic in surrealistic art.

\section{Machine}

The film by Salvador Dali and Luis Bunuel "Andalusian Dog” begins with disgusting shots: someone opens the eye of a young woman with a razor. But the woman continues to see. The film shows what this woman sees, and what she sees is unlike anything. What is it? ${ }^{2}$ What if this reality opens our eyes with a razor? Suppose that after the autopsy our vision has become perverted - really perverted or perverted in the opinion? But what if our vision came into conformity with what it should be by that means? Has it come into compliance with its subject? The one who came out of the Platonic cave, does not see like the one who remained in the cave. Whose look is perverted? "What if this look allows you to see the truth of the perverted world?" - To understand is not enough, you need to see. Celine's hero ("Journey to the End of the Night") realizes that a nation is

\footnotetext{
${ }^{2}$ Luis Bunuel forbade the search for any rational explanation of the images used in the film. See: Капричос. Гойя. Дали. М.: РИП-Холдинг, 2017, с. 27.
} 
a chimera, after a second he sees a marching regiment being thrown by ladies and flowers. And he has been recorded as a volunteer as soon as possible. He becomes a volunteer of the First World War not from the inability to understand, but from the inability to see. - Surrealism sees more than reality, - super-reality. The eye of the surrealist, in his perversion, sees that which is more real than reality itself, that which this reality conceals. - Anyone is able to see pink warm ladies throwing a regiment with flowers, and this is really a reality, but this is such a reality that, in fact, is a fraud: there are not ladies throwing a regiment with flowers, but a war machine - or, if you use this concept, like Deleuze and Guattari, the war machine appropriated by the state machine - and the ladies are not ladies, but its tentacles. Seeing what there is means not seeing what there is. To see things which no one can see - the tentacles for instance, we cannot see them, so that means to see things that are here. "The perverted gaze is the only uncorrupted."

In the film "Andalusian Dog," Dali and Bunuel saw cruelty, absurd cruelty in a modern interior, such as a cut off hand on the pavement, carefully placed by the police in a box. Whose hand is this? Who is this woman poking the hand with a cane? The hand is placed in a box. Street traffic restored. - Andalusian dog, a sissy, that in Madrid the same thing, Andalusian dog nickname of a sissy, first in the bib, then holding a pistol in each hand. An Eve of something scary? "Actually, it doesn't matter what Dali and Bunuel wanted, whether they thought that the 20 s only seemed "golden", covering something quite different, like painted lips cover the mouth of a toothless old woman. Their feelings could be smarter than them. - Feelings can be more stupid than their owner or vice versa. It would be nice if the feelings were smarter or so that we were as smart as the senses, but ... - As for Dali, as his senses stunned, he became closer and closer to the classical forms, in the form in which they were possible - in the form of a vulgar-glossy "Last Supper".

To socialist realism. - The falsity of the warm pink people of socialist realism is that they are machines, issued as people. I do not want to offend anyone: cars are here and there, but we - socialist realists - do not even feel it, we drown out in ourselves this feeling, the feeling that breaks through in them. - In the Tretyakov Gallery there are a monumental canvas by Vasily Efanov "Unforgettable Meeting." It is a very good work. There are a frenzy of color, a lot of joy - joyful wives, 
joyful leaders in this work. What are wives? "The leaders of the Party and Government on the Presidium of the All-Union Conference of the Wives of Business Executives and Engineering and Technical Workers of Heavy Industry in the Kremlin." Full title! Very good title. - Smile and delight under the engine name. - I wonder how advertising agencies call their poster templates? Well, there is no doubt that women with these patterns also smile. - No doubt, Efanov saw what there was. But this is not enough. There is nothing tricky in seeing what Efanov saw, it is more complicated to see what is, but what is not, what is not visible, it is the state's car. We, like people with a perverted gaze, have already seen women throwing flowers, tentacles of a war machine, or if according to Deleuze and Guattari: state machines in the guise of war, now we see tentacles of the state machine in the smiling ladies of the Presidium in the guise of the world.

Strictly speaking, these guises easily transform into each other, they are the same guise. - Smiling ladies confuse us. The state machine needs a suitable face, the face of a smiling lady in order to confuse us.

\section{1/3 - Woman}

Actually, the lady has no face, so her face is suitable for anything, for any advertising. The Truth of a Lady - A Lady Without a Face, Hans Bellmer's Doll.

"An unforgettable meeting" confuses the one who looks, - some woman has already been dreaming of a worker of the heavy industry, but she has doubts: will a worker of the light industry suit? - and confusesthe one who is depicted. They say, Efanov wrote etudes from nature, that is, there were these smiling wives, presumably believing that their partialness is their integrity. Appearance, imagining itself authenticity. - This appearance is not very good in itself, but in our case, the case of "building" a new society, it is not twice as good as a broken clock is not very good in itself, but when you need to catch the train, they are not twice as good . - The wives, or rather, their function, because the wife is only the function of the man's wife, depicts "Doll", and portrays brilliant. Obviously such wives cannot be seen anywhere, neither in the kitchen, nor in the nursery, nor in the presidium - by the way, what were they discussing? Have we got the right to ask about it? Bellmer casts in the metal the things without which there is no wife, - breast and backside. His 
"Doll", like two drops, of water is similar to the Paleolithic Venus. - No, it is not similar, that is, it looks similar in appearance, but in essence it is her direct opposite. The breast and the backside of the Paleolithic Venus is expressed not by the partial, but by the integrity. Earlier, the whole universe exhausted with her breast and her backside; always pregnant and constantly giving birth - Mother Nature. For us, this breast and this backside is not exhausted by anything, for us it is a partial, therefore it is painful for us to see the "Doll". "This is the difference between our view and the Paleolithic view, we, voluntarily or unwittingly, involuntarily, if we succumb to the charm of "primitivism", and this can be put into surrealism, we proceed from a modern point of view, let me say from the point of view of a developed person.

That is why it hurts us to see the "Doll". But we must be hurt! When you see a partial, it must be painful. It is bad not when it hurts, but when it is painfully covered with flowers, sanctioned on behalf of the new society. "From the fact that the" leader "shakes the wife's hand, the wife does not cease to be the breast and the backside. They shake her hand precisely because she agrees to be the breast and the backside. From this point of view, it is better not to have hands, which "Doll" does not have.

"Bourgeois looks at his wife as a mere production tool", Marx and Engels wrote in the Communist Manifesto. - And ... How to portray a bourgeois wife? And the bourgeois with his wife? I won't guess whether Francis Picabia read the Manifesto, but his Love Parade portrays what Marx and Engels write. Of course, Picabia looked at the question with bourgeois eyes, and who looked not bourgeois? - Marx in Capital showed the capitalist use of machines, Picabia in the "Love Parade" showed the capitalist use of women. Wives? Prostitutes? - Never mind.

\section{I $2 \backslash 3$ - A savage}

The head of the Dadaist, Hans Arp, is like the head of an ancestor from Oceania. Heads of ancestors from Oceania, often skulls on a wooden stand, with arms and legs. Hans Arpa has a wooden skull. - It makes no sense to ask what the skull of the ancestor means for the aboriginal of Oceania, for us it is self-knowledge, in which super-realism, surrealism is represented by a real skull. Reality is given by reality itself. At last,

\footnotetext{
3 Маркс К., Энгельс Ф. Манифест Коммунистической партии // Сочинения, 2-е изд. М.: Политиздат, 1955, т. 4, с. 444.
} 
surrealism gives us something that can actually be seen. - If you ask about the origins of our need, the need that turns the skull of the savage ancestor into an object of art, I think I will not be mistaken if I point out the First World War, the war of mass armies and the militaristic rear. - In the already mentioned novel of Celine, we are experiencing the disintegration of the flesh - this is one of the few novels about the disintegration of the flesh, the flesh of Celine falls apart virtuously; and war is only the beginning of its collapse, that observation point, looking around from which we can survey all the richness of these putrefactive forms - from trading posts under the equatorial sun of Africa to musty cabinets in a Parisian suburb. Man everywhere is nothing else than decaying flesh, and, perhaps, the most "hygienic" that can still remain from him - his bare skull.

\section{II. - Eye}

Marx in the Economic and Philosophical Manuscripts of 1844 will not leave his eyes without an eye. If not to bore the reader with popular quotations, then we can formulate like this: we do not see without an eye, but what? And how? The ability to see is determined not by the eye, but by us, we define it as social creatures, and since we are not just social creatures, but also occupying a certain place in society, that is, bearing the curse of the division of labor, partialness, or "professional cretinism". Then we see not everything with the eye, but only something; we see not holistically, but partially. "... the mineral merchant sees only the mercantile value, and not the beauty and the peculiar nature of the mineral; he has no mineralogical feeling." ${ }^{4}$ - It may seem, as it seems to the Surrealists, that the savage sees more, deeper, grasps what escapes us. What more accurately shows the essence of the war, our propaganda poster or the Hawaiian idol of the god $\mathrm{Ku}$ with his mouth littered with dog`s teeth? - Savage, in fact, is not yet aware of the division into a person and a trader in minerals, when a person exists as a poetic beautiful, alas, not valid, and a trader in minerals - as a prosaic, not beautiful, alas, real. But does it follow from this that the savage sees the mineral, its beauty and its peculiar natural form?

Marx speaks everywhere about developed feelings. "It is only thanks to the objectively developed riches of a human being that the wealth of

\footnotetext{
${ }^{4}$ Маркс К. Экономическо-философские рукописи 1844 года // К. Маркс, Ф. Энгельс. Из ранних произведений. М.: Политиздат, 1956, с. 594.
} 
subjective human sensuality is developed and partly generated for the first time: a musical ear that senses the beauty of the shape of the eyes - in short, feelings that are capable of human pleasures and that claim themselves as human essential forces" wealth, and not from poverty; he does not deny the case of the "world history" with its results, but wants this case and these results to be appropriated by us. - Marx does not want back to the savage, but forward to the man! - Today, to return to the savage means to abandon the person, this is the same as with the "Doll" by Hans Bellmer, it returns us to the Paleolithic Venus, but serves not as a statement, but as a negation of the woman; the only purpose of the "Doll" is to hurt us and thereby shake us up, wake us up. In savage art such as the head of God bristling with dog`s teeth, we see our pain.

The savage, precisely because he does not know the split into man and the minerals dealer cannot strive for integrity, he does not know our pain and, ultimately, we cannot vouch that the savage sees the same god as $\mathrm{Ku}$ in the god of war $\mathrm{Ku}$. In turn, we cannot see the eyes of a savage. We always see with our eyes, with the eyes of white people. But our view is looking for this time savage god $\mathrm{Ku}$. - What need drives him? Where is it from?

What and how I see cannot remain constant. Especially since my sense of vision is public. - I cannot see the eyes of Raphael! Doesn't the archaic Cora differ from the pre-Hellenistic Bacchae of Skopas? And the point is not that, or in any case, not only that the obscure sculptor Cora was able to convey only static, but Scopas learned to recreate the whirlwind of movement, the obsession with dance - why did Scopas learn? "Art always can and knows what it wants," wrote one Soviet art historian, "but only what it wants." ancient Sumer, obsessed with huge eyes. Their figurines look at the world prohibitively, eerily, like doors (coffins?), with the eyes wide open. What do they see? What abyss? Or is it just a look of a zealous owner, whose figurine in his absence looks after the slaves? - In short, the things what and how we see always changed, but at the end of the XIXth and in XXth centuries it has changed especially.

\footnotetext{
${ }^{5}$ Маркс К. Экономическо-философские рукописи 1844 года // К. Маркс, Ф. Энгельс. Из ранних произведений. М.: Политиздат, 1956, с. 593

${ }^{6}$ Quoted by: Искусство Древнего Востока // Малая история искусств. M.; Dresden: Искусство; VEB Verlag der Kunst, 1977, c. 88.
} 
It is even strange that some of the Marxists prefer to be surprised: who, if not Marx, spoke about the distinction between a person and a trader of minerals, a merchant and a citizen of a state, a German and a representative of the human race? But this distinction, the boundary of this distinction is within each person. - Who among us is holistic? - You see, Rafael did not lie, but the one who repeats Raphael today will lie. There is no illusion of a holistic person, which Rafael could be perceived as reality, today. - Favorite artist Andre Breton, Pablo Picasso was able to capture this split, see, for example, "Portrait of Daniel-Henry Kanveyler." However, I prefer "The Portrait of the Artist M.V. Matyushin" by Kazimir Malevich. - Yes, people are split, they will tell me, but does surrealism understand this as a problem?

Not; does not understand. But the Marxist philosopher must also do something. Once there is a division of labor.

\section{III. - Market}

Marcel Duchamp, writing a check from a non-existent bank to his dentist, opened or rediscovered financial fraud as an art. The point, of course, is not that Duchamp was a virtuoso of fraud, in truth, he was not even a fraud, his dentist knew perfectly well what kind of check he had received and was not going to cash it, then what did Duchamp discover? Duchamp imitated financial, or as he said: "phenansoviy" operations. Phenansy is not finance; it is an imitation of finance and at the same time something more real than finance. - Plato once blamed Homer for writing Homer about the war, but he wasn't a warrior, Homer spoke about the kings, and did not reign, you can add: he writes about the gods, but he is not God himself. He only imitates, but does not. Duchamp does, but imitates (therefore does not get in the criminal chronicle) and imitates, but does. He makes the program, so - not in the criminal chronicle, his program is the truth of finance, therefore - in the scandalous chronicle. After a couple of decades, Yves Klein, having appropriated the air for himself, will start selling them, and the newspapers will come out with headlines: "Klein is selling air!". - In neither case, nothing is created that could deliver sensual satisfaction, it does not create an object of sensual satisfaction, things, instead, the relation is recreated in its pure form. You see, in the "normal" economic case, the attitude is often hidden, as Marx liked to repeat: it seems that use values, useful things are produced, but 
capital produces value. Another thing is that capital cannot produce value without producing goods, things that ultimately should be useful for someone. Oil or guns are useful to someone, but for the capital that produces them, they are the essence of value. When Yves Klein trades in the air, and Marcel Duchamp offers to sell the air long before him, then ...-Again, since capital produces value, production time, mediating turning Money into Money', is almost annoying inevitability for him; he disdains speculation to reduce turnover to $M-M^{\prime}$ (I don't touch bank capital for which $\mathrm{M}-\mathrm{M}$ is a "normal" turn), and the miracle of $\mathrm{M}$ ' birth out of thin air happens ... This common phrase "make money out of thin air", understood, of course, metaphor In all cases, except in the case of Yves Klein. Klein makes money out of thin air. - Capital would like to do as Yves Klein does, but it is Yves Klein who does it. Duchamp, by the way, although he did not become an air seller, but he became - almost said: its producer, not its producer but a producer of carbon dioxide. "I am a man," said Duchamp, "whose work consists in the fact that he breathes."7

A black or red-figured amphora is both a useful thing and a work of art; through it, the painter and his viewer asserted themselves in being. "Euphimis, the son of Polii, painted, as Euphronius could never have done." Written on one of the bottoms. Over time, the amphoras turned into exchange values, and euphimides and euphronias became slaves, that is, also exchange values. Centuries later, a cult of genius, a "free artist", was born, free also because it does not create anything useful, nothing that could be sold, that is, it creates art for the sake of art. To the extent that Duchamp disposes of something useful - a bottle dryer or a urinal - he does not create it; to the extent that he creates something - like a signature on a fake check - it is completely useless. But this, and the other, is the essence of value, and Duchamp creates them. - Duchamp bought a urinal and sent it to the exhibition. Urinal slid far away. A friend of Duchamp came under the guise of a millionaire, wrote a check for a couple of millions in the name of Duchamp, bought a urinal. I imagine how the curator of the exhibition shouted: "Where is the urinal? Bring him to the main hall! Put in the center! This is the high spot of the exhibition!" The millionaire's check makes the urinal an art. - They say the urinal is lost. If

${ }^{7}$ Quoted by: де Дюв Т. Невольники Маркса: Бойс, Уорхол, Кляйн, Дюшан. М.: Ад Маргинем Преcc, 2016, с. 82. 
he had been, there would have been a millionaire who would have written a real check. That the urinal is an art makes it worth. A split urinal would be good too.

Duchamp does nothing useful, he, like capital, produces value. - If capital produces value, why does Duchampn not demand money, price as such, for breathing?

\section{IV. - Desire}

Why desire? - Desire makes its demand directly. An indirect way to satisfy the desire is the institution. In this distinction, I repelled from the Deleuze distinction of instincts and institutions ${ }^{8}$, but I am not talking about instincts, but about desires, as a human and socially conditioned. Since my examples are from "Journey to the End of the Night", I'll continue the tradition: one of the travelers to this region, Robinson, serving as a delivery man, desired a client, and he desired her because of her silks and lace, her perfume, and the furnishings of the apartment. He desired as a delivery man, that is, he wanted in a specific way for the delivery man. And at the same time, he did not want to satisfy his desire through the institution of marriage, because the institute promised him not a client, but the woman the same as he, smelly and badly dressed, and in addition it promised another smell, the smell of poverty in a stale kennel, that is, a family hearth. - The Institute restrains desire. But this function of the institution still says nothing about what is better - desire or institution? In his articles, Lifshits links desire with fascism. - Indeed, Hitler said: "The great disasters of our people raised us to fight, joined our forces and elevated us. We will never understand those nations that have not experienced such deprivations. It seems mysterious and even incomprehensible to them that hundreds of thousands of people are able to unite in the face of the greatest misfortunes and sufferings. It is not possible for others to understand that this is not happening by order of the state. It's not the state that gives us orders, it's we who are in charge of the state. It was not the state that created our movement, we ourselves created our own state." Not the institution, but desire. It turns out that it is regrettable that the state institution was too weak to neutralize the fascist

\footnotetext{
${ }^{8}$ Seе: Делёз Ж. Инстинкты и институты // Ж. Делёз. Мая 68-го не было. М.: Ад Маргинем Пресс, 2016, c. 18-23.

${ }^{9}$ Hitler's speech at the bottom of the Nazi Party in 1934; cit. according to: «Триумф воли» (Triumph des Willens, реж. Лени Рифеншталь, 1935), 58-ая-62-ая минуты.
} 
desire. Bismarck's institute is better than Hitler's desire. But the Bismarck Institute in the person of Hindenburg itself gave way to Hitler's desire, because ... served all the same desire. - Not desire, not an institution in itself does not guarantee against fascism. From Hitler's desire, it does not follow that every desire is fascist. By this logic, any vegetarian is a fascist.

Duchamp is a disgrace, but not a fascist, because his desire is confusing. Fascist desire restores certainty: the German is German, the Jew is Jewish, the man is man, the woman is woman. A reproduction of "Mona Lisa", corrected by Duchamp's pencil, confuses: you are waiting for a woman, but Mona Lisa with a painted beard and mustaches is already a man. - Is Gleb Ouspensky doing the same with Venus de Milo, declaring that her face is masculine? - This game reveals that not only a woman can cause lust, and not only a man can think. In Mona Lisa, with the mustache of sexuality no more than in Venus, Gleb Ouspensky, although Duchamp refers to sexuality through the signature "L. H. O. O. Q. ", that is, the phonetic anagram of sexual attraction in French. "Mona Lisa" is rather pensive, probably she is already pensive in Leonardo`s painting too: just like Venus de Milo, Mona Lisa does not shine with female (in the traditional sense) charms, but the fact that she is a woman prevents her from being thoughtful. When I read the description of the feminine traits of Baron Charlis with Proust, I understood that there are no longer any grounds for excluding women from among men, men and women are interchangeable. - Is it necessary to approach this through Baron Charles or Rroz Selyavi, she is: Marcel Duchamp in a woman's dress? No, it is not necessary, but for the time being I am interested in the question: is this desire fascist? - No, it's not.

\section{V.}

In short, a "wishing machine" can be blamed for the fact that, shaking the existing one, thanks to the revolutionary nature of its desire, it is nonetheless unable to overcome its grip. To do this, you need to take a fundamentally different position to the existing one - not the automatic recorder, but the author. - The author's denial is what unites Breton, on the one hand, Deleuze and Guattari, on the other; and the latter give the author's negation a political meaning. After fascism there cannot be the author. - I think that this is as (not) true as the Lifshitz logic: after fascism there can be no desire. From the fact that Hitler is the author (if he is the 
author), it does not follow that every author is Hitler. - If you put the question politically, the risk of fascism is not in the position of the author, but in the position of the automatic recorder. Even if fascism comes from the author, then it comes from a certain (one) author and, in order to spread, needs no other authors, but automatic recorders. In other words, the risk of fascism is the less, when there are more authors. Actually, Deleuze and Guattari themselves distinguish protest, revolutionary desire "no, I am not yours" and conformist, fascist desire "yes, I am yours", in my opinion, it is not difficult to understand which of the two corresponds to the position of the author, and which automat.

\section{VI. - To slip!}

Andre Breton's manner of combining fragments of words with fragments of objects is not original; it was in this manner that Carlo Carra, the Italian futurist, responded to the First World War, alas, responded in a fascist manner - his invasion appearance collage was published under the heading "Patriotic feast". - Perhaps, right now I come to criticism of the recorder's manner. - Andre Breton is not a patriot, Carlo Carra was not a patriot either. - Carlo Carra enters the pictorial art with the painting "The Funeral of the Anarchist Galli", written sympathetically to the anarchists, to Galli, the anarchist who was killed during the Milan strike of 1904. And the picture cannot be called an accident, Carra hatched her from 1904 to 1911th. How did Carra become an adherent of war? Very simple: he listened. "I expelled every image of a person," he said, "in order to portray the pictorial abstraction of the urban bustle." 10 The city hustle shouted about the war, and Carra shouted about the war. Carra read Marx, but turned out to be no smarter than the hustle. - It is not enough to listen to the commotion to keep pace with the times. To keep up with the times, you need to run forward - to slip away from the hustle.

It is difficult to say what prompts to escape, perhaps, desire, the most protest one: "no, I am not one of yours". Although futurism unites F.T. Marinetti and Vladimir Mayakovsky, desire separates them. I think that it is because of the difference in desire that the difference in their political positions results. Marinetti wants to listen to the roar of automobile engines under the windows and listens with ecstasy to a provincial who wants to pass for the capital's inhabitant. - Italy - a

\footnotetext{
${ }^{10}$ Quoted by: Мартин С. Футуризм. GmbH; M.: Taschen; Арт-Родник, 2010, с. 66.
} 
province of Europe, Marinetti - a diligent provincial. - Mayakovsky also listens, but maybe even unconsciously takes a different position for himself: already in the "Adishche of the city" ... It seems to me that the old man, brought down by the tram, is still pitiful, and then for some reason, after all - an awesome! - The old man began to cry. And, in my opinion, we see these tears. - Then "Good attitude to horses." The street hustle is expressed perfectly. Mushroom! Rob! Coffin! Rude! But Mayakovsky somehow escapes the hustle: when everyone laughs at a fallen horse, he sees horse`s tears. - Again the tears. - Horse`s anguish spilled on him.

Slipping, drawing a line of escape is what Gilles Deleuze and Felix Guattari love to write about. Only their line - turning into an animal, a plant, a stone. - Is not this a recognition of his defeat? What is tricky to turn into an animal? Or, in other words, is not the non-transformation into an animal not worth us much more effort? - It seems that Mayakovsky escapes under their scenario. - Each of us is a horse of his own. But what if a horse becomes a man here? - Everything seemed to her, she was a foal, and it was worth living and working was worth it. - To live and work in a horse or human way? If the horse were to work in a horse-like manner, a verse would hardly have made on us that renewing effect that it produces. We are all horses, we are all driven horses. - What if a horse becomes a man? Even a better person than laughing faces at Kuznetsky a participant in the revolution. Still, the 18th year! Hence its update. "She thought she was a foal, and it was worth living and working."

Then the horse slipped away from its share of the horse due to the fact that it did not listen to the commotion, but surpassed it, overcame it, because it saw what it was worth living and working for. - Marinetti gives the futurism formula: "art + action + life = futurism". But does he follow this formula? Listening to the roar of car engines does not mean acting, it means just listening. You can listen to grasshoppers, you can listen to motors, it is a matter of taste and opportunity: if there is no possibility to leave the city for the summer, then listen to the motors. - Action is in another thing, and it means that Marinetti is not a futurist, but only a pastoralist in a new way. 


\section{VII. - About imagination}

It would be wrong to end the conversation without saying about Guillaume Apollinaire, the author of the word "surrealism." At Apollinaire, as well as at Breton, the children's dream and adult everyday life, the dream of something worth living and working, and the hustle of the gray Parisian streets cannot come together. - It should be noted that Apolliner's perception of Paris is not at all romantic, in his second compilation published during his lifetime, "Alcohol", he introduces us to Paris from the backyard, from the Zone, or the working outskirts. The same Zone is the scene of Parisian action in Celine's novel, "Journey to the End of Night". - A sultry modern world, cars, horns, brutal sun, dust, gasoline stench, a crowd in which everyone is in a hurry on a business, a very important business, their business, eliminates the dream, makes it silly and shameful. There is nothing to breathe from rushing cars - it is not so easy to work as Duchamp, - but what else is left? What is not stupid? What is not ashamed? - "You're in Paris. You are completely alone in the crowd, and you wander without knowing where. Immediately, next to you, there appear a lot of mooing buses. Her throat gripped her longing with her sharp hoop, as if you would never be loved again. If you had lived in another era, it would probably have been tonsured as a monk, and now you are ashamed to pray when your soul is bad. You laugh at yourself and in your laughter - sparks of hell. With gold they cover the canvas of your life. This canvas was hung in a sad museum. There you come to look at him sometimes."11 - By the way, about canvases, canvases, if they express something, they express pain, and Apollinaire was friendly with Picasso, there is even a roll between the "Girl on the ball" of the second and the "Cloudy ghost" of the first. - "You're in Paris. Here women are spattered with blood scarlet. It was (oh, I don't want to remember!) It was at a time when beauty was dying." ${ }^{12}$ - Where is the blood from? In Celine, blood flows from the uterus torn by an abortion; this is his medical practice. And since I'm following Celine as my shadow, and he really is a shadow, a shadow of fascism, doesn't it pose the question that in this decaying, bleeding uterine blood can prevent you from becoming a fascist? Celine has become. I don't want to give a "schematic" answer, strictly speaking, nothing but ... Celine doesn't have

\footnotetext{
${ }^{11}$ Аполлинер Г. Зона // Гийом Аполлинер. Стихи. М.: Наука, 1967, с. 26.

12 Ibidem, c. 26.
} 
a dream or, in any case, he's part with it quite easily. A childhood dream is shameful because adults have finished it long ago, but the most humane, in any case, as long as childhood remains for us the only time when we are driven by a variety of feelings, from kind curiosity to proud ambition (when, if not in childhood, read the history of the Roman Republic?), but our feelings, not alienated, are of interest, but not from the English interest, a percentage of capital.

No matter how we are crippled by the cares of various trainers, childhood does not lose its charm for us. Andre Breton writes in "The First Manifesto". - Maybe the simplest surrealist act is not the one that Breton declared with a completely childish provocation in "the Second Manifesto" - go out and shoot a pistol - and admit to yourself and others in your childhood dream? - By the way, I take Breton's statement as a child's provocation; you accuse me, God knows what, I confess to you! Take it! I'm worse than you thought! You can be happy! "Didn't it happen to us to do the same?" "You have no shame, no conscience!" - It does not matter here whether they are (maybe they are), the rules of the game require their denial. - Maybe even the most conscientious would rather recognize the lack of conscience? - How infantile it turns out! And what prevents us to prove that Hitler carried out the simplest surrealist act, and for me, and for Breton? Frankly, I would prefer to leave Hitler alone now, especially since he has become a baton, used, depending on the case, against desire, now against the author, then against anything - let's agree that man is a being entered to sin, to fascism, to anything, and let's go on. - Presumption of innocence.

"Here is a familiar street, again it is young, and you are just a child. Mother dresses you in blue and white. You are very inspired and delighted with the pomp of the service. Your friend Delize shares your admiration." ${ }^{\prime 13}$ - Now the sky is for airplanes, Christ is competing with them. - What torments Apollinaire? The very thing that tormented Mayakovsky's horse. What should we live and work for? A very nonbourgeois (possibly reactionary) question, which is based on the assumption that there is something, something more worthwhile than interest on capital. - Feudal socialism? I hold the opinion that without this strange thought, Marxism would not have been born, perhaps the"

\footnotetext{
${ }^{13}$ Аполлинер Г. Зона // Гийом Аполлинер. Стихи. М.: Наука, 1967, с. 24.
} 
immaturity "of the Germans, as compared with the efficiency of the British, also played a role here ...

"All the gods were waiting for these graveyards,

Waited tears of weeping willow.

Pan Great, Love and Christ

Now they are dead, and the cats mew,

I brought my grief to Paris.",

I brought my grief to Paris, on Cristin Street, on Monday, "Monday on Christin Street", a completely surrealistic verse, more real than reality, made up of fragments of street phrases, - Christin Street absorbs me like Carr's - headlines of patriotic newspapers. If I can slip away, it is only because I have a different perception, another - because I came to this street with different memories:

"I, in whose memory Le and Rondeli,

Queens of pleasure,

Song of the siren about rocks and shoals

The anthem of the slaves and the sad tune

Those who did not have happiness in love." 15

The dream does not make over Christin Street. But it is enough that it allows not only to slip away to Apollinaire himself, but also gives him the capacity for sympathy; the special purpose of the bohemian, when the poet takes upon himself the pain of the outcasts, appears in his poetry more than clearly: as Proteus, Apollinaire changes appearances - either an emigrant, a Jew, or a prostitute. We have already heard that beauty is dead, the snow-white Beauty Mallarmé died, and what was left? The one that remains cannot be called beauty, but it also throws a reflection on it, or rather, say, and the echo of le and rondela is heard in it. - "These women are not angry, but they have a lot of worries. Even the one that is not at all beautiful bears grief to the lover. She is the daughter of the policeman which serves on the island of Jersey. Her hands - I had never seen them - hardened, the skin cracked from the cold. The scar on her body causes great pity in me. I now defile my lips for the sake of a poor

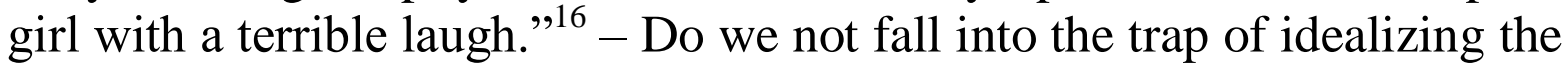
lumpen-proletariat? Very likely; nonetheless - sympathy. - Sympathy is what distinguishes Apolliner from Celine. Celine has a decay of flesh, but

\footnotetext{
${ }^{14}$ Аполлинер Г. «Всех богов этих ждал погост...» // Гийом Аполлинер. Стихи. М.: Наука, 1967, с. 37.

${ }^{15}$ Ibidem, c. 37.

${ }^{16}$ Аполлинер Г. Зона // Гийом Аполлинер. Стихи. М.: Наука, 1967, с. 30.
} 
no sympathy; Celine quite frankly says that as a doctor he lost the ability to sympathize, the only thing left for him is fear for himself, what will it turn out for me? - On the other hand, Apollinaire looks at the Zone as a slacker poet, Celine as a medical practitioner. - I now remembered Celine only for the sake of comparison. The ability to dream gives Apollinaire sympathy ... Having desecrated his lips with the kiss of the terrible girl, he goes home, where idols from the islands of Oceania are waiting for him, and every idol is Christ. - It turns out, Christ links all parts of the "Zone", Christ in the clouds of a child's dream, Christ in a terrible girl, Christ in idols from the islands of Oceania, Christ in the Zone. - If we accept Christ as a longing for something human, and accept that this longing lives in the Zone, then Apollinaire's wandering dream can be "tied" to a new earth, to the Zone. And...

"Sun with a cut throat.",

If the sun rises in the Zone, it should rise with a throat cut.

\section{VIII.}

To the extent that we belong to the commotion of the streets, surrealism gives us a sense of anxiety; to the extent that we escape the hustle and bustle of the streets, surrealism animates our dream. These two, in general, opposing moments are brought together in Breton's "automatic writing" - I write down both that and that, I am not fenced off either from imagination or from the street. - Maybe not enough effort - the efforts of the mind? - to empower the imagination, to change the street. At the same time, we should not forget that we are talking about a certain form of sensuality, and the political meaning here is not the thesis - to change the world - but the feeling of pain, the feeling of insufferable something. I cannot, I'm choking! - Feeling absurd.

$$
* * *
$$

In Apollinaire, all these feelings are ennobled by a dream. - Where the hustle of the streets is a modernist form, where the dream is almost a classical form. However, both that, and that - interlacing threads of one cloth. - Interlacing threads ... Much is intertwined in surrealism, it is not so easy to intertwine Apollinaire and, say, Duchamp, with each other from that I wonder if my article has not been dispersed in different directions? - Is it possible to catch the feeling that all this will

\footnotetext{
${ }^{17}$ Аполлинер Г. Зона // Гийом Аполлинер. Стихи. М.: Наука, 1967, с. 31.
} 
intertwine? - Andre Breton intertwines everything with a political gesture: "Le Surrealisme au service de la revolution". He puts all parts of surrealism on the revolution, as if on a rod, and thereby gives them meaning. In the service of what? In the service of the revolution. - What is the result of the revolution from surrealism?

\section{IX.}

My first acquaintance with Lorelei took place thanks to the Mandelstam line: "Russia, Leta, Lorelei." The beauty Lorelei was accepted by me, I repent, for the dadaist set of sounds that are consonant with Lethe, for such a le, rondel, riturnel. Apolliner enlightened me. And I felt the connection. - Lorelei is the name of a dream, and when you consider that Mandelstam ends his verse "Decembrist" with this line, it is not just the name of a dream - dream of revolution.

"To the blonde witch from the Rhineland

Men were walking in a crowd, dying of love." 18

They, we go, we go to Lorelei, Lethe absorbs us and them, and again, and again ... They go and we go. - Beauty Lorelei, wanting to stop the flow of people, rushes into the Rhine stream. - Where to go now? - The beautiful Lorelei does not realize that it is better to go to her than not to go anywhere. We, feeling (understanding?) It, do not pass judgment on her. The bishop, called to judge, cannot judge.

"O Bishop, in my eyes the flames of fire,

So give this terrible spell to fire!"

"Lorelei! Your fire is omnipotent: I'm

bewitched by you not a judge to you.",19

The one who is seized by desire cannot judge him, but also the one who is not already seized does not have the right to judge him. Desire is not subject to jurisdiction. When the Rhine's waters close over Loreley, the object of desire will disappear, but not the desire itself. Peace will not come. Now the possibility of peace is even less than it was before, since the desire can no longer be satisfied under any circumstances. Desire is doomed to remain unfulfilled. - Socialist realism chooses to quench desire by portraying Lorelei in legal marriage, surrealism leaves desire unsatisfied. - Social Realism chooses to see the revolution complete, surrealism lasting. Strictly speaking, Social Realism is also not realism,

\footnotetext{
${ }^{18}$ Аполлинер Г. Лорелея // Гийом Аполлинер. Стихи. М.: Наука, 1967, с. 70.

${ }^{19}$ Ibidem, c. 70.
} 
and the question is, what serves revolution, satisfied desire or an unsatisfied desire? - The bourgeois knight, still remembering that he is a knight, reluctantly going to go to Lorelei - where else to go? He hears Lorelei drowned: "Thank God!" He is quite satisfied. - My claim to socialist realism is that it is satisfied. A milkmaid is a milkmaid; a pigwoman is a pig-woman. All certainties are restored - very good! - The surrealism of certainty destroys, it is dissatisfied and this serves the revolution. - On the one hand, the attempts of Andre Breton to link surrealism with the revolution seem to be his personal predilection, on the other, ... Andre Breton is not so stupid as not to catch the connection between unremitting desire. Strictly speaking, desire can only be unremitting, and a lasting revolution - desire, that wishes, and a revolution that lasts.

\section{CONCLUSION}

Marxist aesthetics sees rather, the enemy in surrealism, surrealism in Marxism, rather, an ally. Curious mismatch. - It seems that Marxism like surrealism is stretched between the objective and the subjective, the objective that a Marxist should learn under the name of objective laws while the surrealist should record it automatically under the name of the hustle of the streets, and by the subjective that exists, but does it exist? The problem is in the subjective, in its disappearance in the objectified machine mechanism, not at all created by nature and being in this sense the objectification of the subjective, but excluding the subjective, as its mechanism, movement is determined by its own laws. - There is no place for the subjective in the machine assembly. - When Francis Picabia represents the feeling of love through a "love parade", that is, the mechanical movement of the cylinders and pistons, the feeling, like the subjective, disappears and the objective mechanics of the bodies remain; the mechanics of their movement, something like an internal combustion engine. - The scandal that such constructions produce in Marxist aesthetics is rather intended to cover up that it is not enough to cover the car with leather and draw a blush on it in order for it to become a man. In other words, it is called upon to cover up doubts that social realism (another realism with a prefix) gives us people.

The paradox in the combination of decisive revolutionism, "Surrealism at the service of the revolution" is the name of Andre Breton's organ, a rejection of the subjective, in which even desire is understood as something objective, some objective movement of cylinders 
and pistons under the influence of incoming flows, for example, hot steam flows. - At the same time, the spectator perception of surrealism is much more subjective, more scandalous than the perception of the social realism. Maybe the scandal here is something more than just attracting attention (although this too), it is a blow, a shake that makes you think. Maybe it is through the scandal that our subjectivity is introduced into the game. - The scandal produced by surrealism is the same scandal as the scandal made by Capital, the outcry scandal. This is the first thing; and the second one is that through the scandal, the subjective is introduced into surrealism. And it must be entered as in Marxism, since it is possible to learn the objective or record the hustle of the streets, but the objective one cannot change the hustle and bustle of the streets without the subjective. The scandal of exposure requires our reaction, I of course do not speak of epigone scandals that do not aspire to anything else but to tickle nerves. But how to distinguish the one from the other? It is not so difficult, it is our political sensuality that gives us the cue about the scandal. It distinguishes and it constructs the scandal as political. The scandal of exposure cannot take place without it. In other words, in order for the surrealist actions to be more than disgraceful, it must be assumed that, while behaving disgracefully, they serve the revolution. "At the service of the revolution" is the key to their disgrace.

\section{SUMMARY}

Mikhail Lifshits, one of the few original Soviet aesthetics, made a non-original statement: the avant-garde logically (!) leads to fascism. Since it is impossible to embrace the entire avant-garde in one article, I focus on one thing, on surrealism. Why surrealism? Because its founder Andre Breton unambiguously declared his political position, strictly speaking, this position is already read in the name of the Breton magazine - "Surrealism in the service of the revolution". Of course, you shouldn't take Breton for a word. Therefore, the aim of the article is not to clash two statements with each other - Lifshits and Breton - but to trace again the logical (!) connection between surrealism and revolution. First of all, a revolution, whether political or surreal, is not at all obligated to be chaste, as Miche Lifshits probably believes. Although it is not limited to this, it does not exist without it, without an exposure scandal. It is interesting to note that it is not worth the trouble to give the statements of Marx interpreting the revolution precisely as an exposure, however, an exposure produced by political means. Surrealism does the same work. It 
also exposes bourgeois reality from ideological veils that hide it, but by means of art. It is this nudity, desire and ability to see more of what reality wants to show us in which consists a positive answer to the question "does the surrealism of the revolution serve?"

\section{REFERENCES}

1. Аполлинер Г. Стихи. М.: Наука, 1967. 335 с.

2. Де Дюв Т. Невольники Маркса: Бойс, Уорхол, Кляйн, Дюшан. М.: Ад Маргинем Пресс, 2016. 112 с.

3. Делёз Ж. Инстинкты и институты // Ж. Делёз. Мая 68-го не было. М.: Ад Маргинем Пресс, 2016, С. 18-23.

4. «Если бы наша консервная банка заговорила... Михаил Лифшиц и советские шестидесятые» 7 марта - 13 мая 2018. М.: Музей современного искусства «Гараж», 2018. 25 с.

5. Искусство Древнего Востока // Малая история искусств. М.; Dresden: Искусство; VEB Verlag der Kunst, 1977. 375 с.

6. Капричос. Гойя. Дали. М.: РИП-Холдинг, 2017. 261 с.

7. Маркс К. Экономическо-философские рукописи 1844 года // К. Маркс, Ф. Энгельс. Из ранних произведений. М.: Политиздат, 1956, C. 517-642.

8. Маркс К., Энгельс Ф. Манифест Коммунистической партии // Сочинения, 2-е изд. М.: Политиздат, 1955, т. 4, С. 419-459.

9. Мартин С. Футуризм. GmbH; M.: Taschen; Арт-Родник, 2010.95 c. 1935)

10. Триумф воли (Triumph des Willens, реж. Лени Рифеншталь,

\section{Information about the author:}

Predeina M. Yu.

Candidate of Philosophical Sciences, Senior Lecture at the Department of Philosophy and History,

V. I. Vernadsky Taurida National University, 33, Ivana Kudri str., Kyiv, Ukraine.

E-mail: m.y.predeina@gmail.com 